\title{
Comparative Performance of Physicochemical and Diatom-Based Metrics in Assessing the Water Quality of Mert Stream, Turkey
}

\author{
Faruk Maraşlıoğlu', Serdar Bektaş², Arda Özen ${ }^{3}$ \\ 1 Department of Biology, Faculty of Arts and Science, Hitit University, Çorum, 19040, Turkey, e-mail: \\ 2 Department of Biology, Faculty of Arts and Science, Ondokuz Mayıs University, Kurupelit, Samsun, 55139, \\ Turkey, e-mail: serdarbektas@mynet.com \\ ${ }^{3}$ Department of Forest Engineering, Faculty of Forestry, Çankırı Karatekin University, Çankııı, 18200, Turkey, \\ e-mail:ardaozen@karatekin.edu.tr \\ * Corresponding author's e-mail: farukmaraslioglu@hitit.edu.tr
}

\begin{abstract}
In this study, the authors aimed to compare the performance of the physicochemical-based water quality metrics (WQI, SWQMR) and diatom-based diatom metrics (TDI, BDI, GDI) to evaluate the water quality and ecological status of the Mert Stream. A total of 104 epilithic diatom species, belonging to 44 genera, were recorded during the study period. Navicula was the most dominant diatom in the sites near intensive farming areas, while Gomphonema was the most dominant species in the sites in vicinity of urban and industrial settlements. According to the water quality indices based on the physicochemical parameters and diatoms, the water quality in the upper and middle parts of the Mert stream was better than in the lower parts (higher amount of total suspended solids and higher conductivity). The structure of the epilithic diatom community was mostly shaped by total suspended solids, electrical conductivity and nutrients according to Canonical Correspondence Analysis results. The obtained results revealed that diatom metrics, especially GDI, and water quality metrics, especially WQI, can be used for the monitoring of lotic systems and provide useful complementary information on the ecological status of rivers in medium rainfall regions such as Samsun.
\end{abstract}

Keywords: diatom index; water quality index; epilithic; pollution; stream; CCA

\section{INTRODUCTION}

Anthropogenic eutrophication becomes a serious problem, which threatens the freshwater ecosystem worldwide due to the enrichment of water nutrients resulting from the industrial and intensive agricultural activities and leads to the deterioration of the water quality of rivers and lakes [Vörösmarty et al. 2010]. The bioindicatorbased indices provide a valuable complement to the traditional physicochemical measurementbased indices to evaluate the ecological health of aquatic systems [Pandey et al. 2018].

The Water Quality Index (WQI) is an important tool for determining and categorizing water quality based on the use of physicochemical standard parameters [Hanh et al. 2011]. The
WQI provides a single number ranges from 0 to 100 which show better water quality with higher index values. WQI turns complex water quality data, which consist of several numbers of parameters, into the information that is understandable and usable in the management of water [Chaurasia et al. 2018]. However, the indices using only physical and chemical parameters may not convey the information on the impacts of environmental stresses on organisms. Several different organisms such as phytoplankton, macrophytes, macro-invertebrates, are also used for representing the whole picture of the biological health of lotic ecosystems [Chen et al. 2016].

The diatom indices are extensively used to assess the ecological status of rivers because of the ubiquitous presence of diatoms in lotic systems 
[Sebastiá et al. 2013] as well as their rapid and varied response to changing bottom-up and topdown control factors [Liu et al. 2016, Stevenson et al. 2008]. Therefore, they can be used for the past, present, and future water quality assessment since they reflect the ecological status comprehensively [Almeida et al. 2014]. Diatoms have been used as bioindicators since the 1970s. Nowadays, the diatom indices are widely used for evaluating the water quality all over the World [Descy, Coste 1991, Prygiel, Coste 1993, Lenoir, Coste 1996, Kwandrans et al. 1998, Smol, Stoermer 2010]. Among the several biological indices based on diatom assemblages, the Biological Diatom Index [Lenoir, Coste 1996, Coste et al. 2009] has been widely used in the world, especially in France for monitoring of water quality. However, there are still disagreements on the transferability of the diatom indices to rivers in different geographic regions [Gomà et al. 2005, Tan et al. 2013].

The standardized BDI was first developed and applied in France [Lenoir, Coste 1996] and revised (BDI-2006) [Coste et al. 2009] for the European Water Framework Directive (WFD) and it has been used widely in Europe [Almeida et al. 2014], China [Chen et al. 2016], and Africa [Bere et al. 2014] for the evaluation of water quality, due to its usefulness in the ecological assessment. Trophic Diatom Index (TDI) was developed for English streams and rivers [Kelly et al. 2001] and have been used in Australia, Europe, North, and South America, and Asia [Prygiel, Coste 1993, Lobo et al. 1995, Jüttner et al. 1996, Kelly, Whitton 1995, Gómez, Licursi 2001, Newall, Walsh 2005], and Turkey (Gürbüz, Kıvrak 2002, OngunSevindik, Küçük 2016, Temizel et al. 2017]. The generic diatom index (GDI) proposed by Rumeau and Coste [1988] is also based on the generic composition of assemblages.

In Turkey, the use of physicochemical parameter-based indices is also the traditional tool to monitor and evaluate the surface water quality. Water Pollution Control Regulation (WPCR) [Anonymous 2008] and Surface Water Quality Management Regulation (SWQMR) [Anonymous 2016] are currently being used for these purposes. Although numerous phycological studies using algae as bioindicators have been conducted in different Turkish rivers, the use of diatoms in biomonitoring is relatively new in Turkey [Solak et al. 2012].

However, the efficiency of biotic indices in assessing the water quality in comparison to the physicochemical-based indices is still questionable. Although there are many studies, which compared different biotic indices [Ravera 2001, Semenchenko, Moroz 2005, Hering et al. 2006], there are few studies, which compared the effectiveness of WQI and diatom indices [Pham 2017, Pandey et al. 2018]. Maraşlioğlu et al. [2018] used the physicochemical parameters with modified WQImin to evaluate the water quality of Mert Stream. They found that there were significant variations in water quality index from poor quality to good quality.

In the studies carried out in Turkey; firstly, TDI, SI, GI, and DAIpo indices were used by Gürbüz, Kıvrak [2002] in the Karasu River, and they concluded that TDI and SI were better suited to the physicochemical parameters. The TDI, BDI, SI and PTI diatom indices were used in the Pazarsuyu Stream by Temizel et al. [2017] and they stated that TDI, BDI, and SI reflected the water quality in the Pazarsuyu Stream, while the PTI index does not reflect the actual status of the stations on the studied system. However, DI-CH and TI better reflected the changes in the Isparta and Dariören stream's water quality [Kalyoncu et al. 2009], while DESCY seems to be the best for the Akçay stream [Solak et al. 2007]. Furthermore, TDI, SI, and TDIL indices had a high correlation with physicochemical parameters in the Acarlar Floodplain Forest [Ongun-Sevindik, Küçük 2016].

In this study, it was aimed to evaluate the merits of different physicochemical-based metrics (WQI-SWQMR) and diatom-based metrics (BDI-TDI-GDI) in assessing the water quality of a set of human-impacted sites in the Mert basin, Turkey by comparing the reliability and suitability of these indices. The diversity of epilithic diatom algae and factors that control their distribution was also evaluated in our study.

\section{STUDY AREA}

Mert Stream is located within the border of Samsun Province in the Central Black Sea Region of Turkey (between 4109'02"-41'17'04" $\mathrm{N}$ and $35^{\circ} 8^{\prime \prime} 04^{\prime \prime}-3621$ '50" E). The west of the stream is located by Kizllırmak River and Mert River Basins, the south by Yeşilırmak River Basin and the east by Abdal Creek Basin. Mert stream originates from the Karadağ locality, known as Toptepe, located at $1150 \mathrm{~m}$ altitude in the Ladik district. In the Kavak district, after the stream merges 
with Karataş Creek, $24 \mathrm{~km}$ from the sea and it is the largest tributary, it takes its name, which is called the Mert. Mert stream is very important for the region since it is the irrigation resource of some villages on the route. Its maximum flow is $750 \mathrm{~m}^{3} / \mathrm{s}$. The width of the stream bed is $50 \mathrm{~m}$, while the depth of the stream decreases to less than $50 \mathrm{~cm}$ in the summer months, in winter the depth reaches again 4-5 m. The alluvium thickness of the Mert stream ranges between 10-40 m. The alluvium is usually composed of gravel, sandy coarse gravel, blocky gravel and clay layers [Bakan, Şenel 2000].

The samples were taken at four stations, along with Mert Stream at two regions with different land-use types: intensive farming is present in the upper (St1-St2) and middle (St3) course sites and urban and industrial settlements present in the lower course site (St4). The stations in this study were determined as follows to represent the entire stream; 1st station (4109'50" N, 3605'59" E) is a location between the Küçükçukur and Ahurlar villages which is $67 \mathrm{~km}$ from the Black Sea, 2nd station $\left(4103^{\prime} 38^{\prime \prime} \mathrm{N}, 35^{\circ} 58^{\prime} 41^{\prime \prime} \mathrm{E}\right)$ is at the point where the Mert stream merges with Çamlıdere creek, 3rd station $\left(41^{\circ} 07^{\prime} 13^{\prime \prime} \mathrm{N}, 36^{\circ} 09^{\prime} 41^{\prime \prime} \mathrm{E}\right)$ is in the Mert village and 4th station ( $\left.41^{\circ} 15^{\prime} 54^{\prime \prime} \mathrm{N}, 36^{\circ} 20^{\prime} 35^{\prime \prime} \mathrm{E}\right)$ is at the point where the Mert stream merges with Yllanll creek in the Canik district $(2.3 \mathrm{~km}$ from the Black Sea). The study area (Mert Stream) and sampling locations are shown in Figure 1 [Modified from Maraşlığlu et al. 2018].

\section{MATERIALS AND METHODS}

\section{Physicochemical analyses}

The surface water collection and in situ water quality measurements such as water temperature, $\mathrm{pH}$, DO, and EC were performed monthly between July 2011 and June 2012 at four sampling stations in Mert Stream [Bektaş 2016]. Moreover, total suspended solids (TSS) and dissolved nutrients, i.e. ammonia $\left(\mathrm{NH}_{4}^{+}\right)$, nitrate $\left(\mathrm{NO}_{3}^{-}\right)$, and orthophosphate $\left(\mathrm{o}-\mathrm{PO}_{4}\right)$ were analyzed according to Bektaş [2016] in the laboratory of Ondokuz Mayıs University.

\section{Diatom analysis}

At each site, the samples of epilithic algae were collected monthly from randomly selected

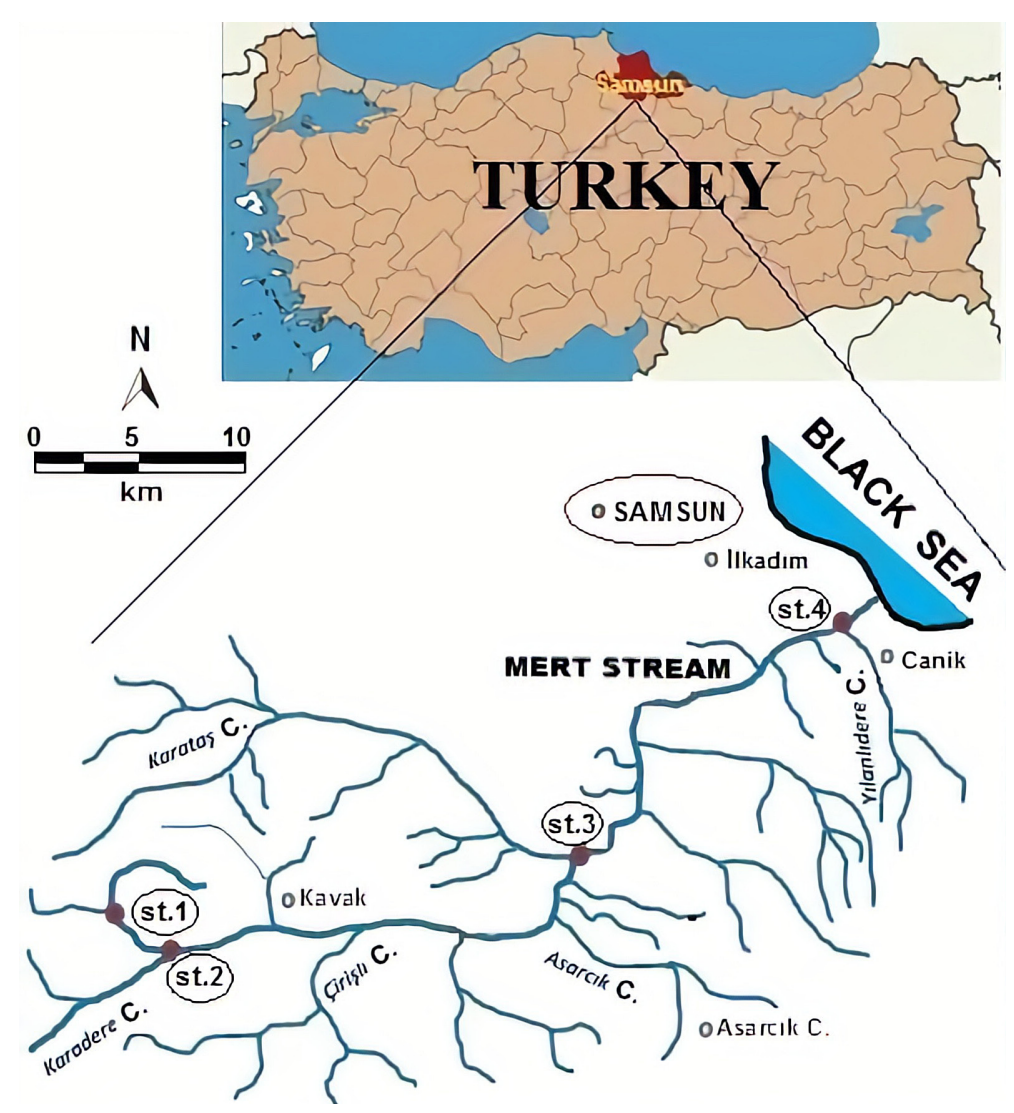

Figure 1. Study area (Mert Stream) and sampling point locations 
cobbles $(n=4)$ in the riffle zone of streams from July 2011 to June 2012. On each cobble, a sampling area of an algal patch of $12.5 \mathrm{~cm}^{2}$ was scraped with a toothbrush (total surface area of $50 \mathrm{~cm}^{2}$ for four algal patches). The cobbles were subsequently washed with $50-100 \mathrm{~mL}$ of distilled water and fixed with $4 \%$ formaldehyde [Yu, Lin 2009].

In order to identify the diatom frustules, the diatom valves were cleaned using hydrogen peroxide to eliminate organic matter and with hydrochloric acid to dissolve calcium carbonate [Della Bella, Mancini 2009]. Clean diatom frustules were mounted in Entellan and a minimum of 400 valves were counted and identified to species or variety level in each sample using a light microscope (Olympus $\mathrm{BX} 51)$ at $400 \mathrm{X}$ magnification. Species identifications were based primarily on Krammer, Lange-Bertalot [1991-1999] and Round et al. [1990]. AlgaeBase web [Guiry, Guiry 2020] and Turkishalgae web [Maraşlıoğlu, Gönülol 2020] were used for the classification and verification of the currently-accepted taxonomic names of phytoplankton.

\section{DATA ANALYSIS}

The values of electrical conductivity, $\mathrm{pH}$, dissolved oxygen, total suspended solids, and temperature have contributed to the calculation of WQImin, by the method of Akkoyunlu, Akiner [2012]. Following the calculation of the WQImin value by the related formula, the WQI value of the stream is obtained practically by placing the WQImin value in the second formula. Detailed information on the calculation of the water quality in the Mert Stream can be found in Maraşlıoğlu et al. [2018]. WQI is a number between 0 and 100 . Water quality is classified as very poor (0-60), poor (61-80), medium (81-90), good (91-95), and excellent (96-100) [Akkoyunlu, Akiner 2012].

Water quality classes, determined according to the Republic of Turkey Ministry of Agriculture and Forestry [Anonymous 2016] based on some physicochemical parameters, are shown in Table 1.

Trophic Diatom Index [Kelly, Whitton 1995, Kelly et al. 2001], Generic Diatom Index (based on genera) [Coste, Ayphassorho 1991], and Biological Diatom Index (the new version of BDI-2006) [Coste et al. 2009] were used to characterize the epilithic community at each site [Agrawal, Gopal 2013]. The trophic status and water quality classes, belonging to the BDI, GDI, and TDI values [Kelly, Whitton 1995, Szulc, Szulc 2013] are given in Table 2.

The relationship of the physicochemical variables at each station with months, seasons, and total organisms was tested through Spearman's correlation. The difference levels between physicochemical variables and stations, months, seasons and total organisms were tested by one-way variance analysis (ANOVA). Additionally, the relationships among metrics (TDI, BDI, GDI, WQI, SWQMR) and the seasonal and station-based relationship with metrics were tested through Pearson correlation. All these correlation and difference tests were performed in SPSS 22.0 program.

The main environmental factors that shape the epilithic diatom community were determined by means of Canonical correspondence analysis (CCA) using the MultiVariate Statistical Package (MVSP) program version 3.1 [Kovach 1998]. All data were

Table 1. Water quality classes according to Water Quality Management Regulation of Turkey for Inland Surface Waters (SWQMR)

\begin{tabular}{|c|c|c|c|c|c|}
\hline \multirow[b]{2}{*}{ Water quality parameters } & \multicolumn{4}{|c|}{ Water quality classes } & \\
\hline & $\begin{array}{c}\text { I } \\
\text { (excellent) }\end{array}$ & $\begin{array}{c}\text { II } \\
\text { (good) }\end{array}$ & $\begin{array}{c}\text { III } \\
\text { (fair) }\end{array}$ & $\begin{array}{c}\text { IV } \\
\text { (poor) }\end{array}$ & \\
\hline Water Temperature $\left({ }^{\circ} \mathrm{C}\right)$ & $\leq 25$ & $\leq 25$ & $\leq 30$ & $>30$ & \\
\hline $\mathrm{pH}$ & $6-9$ & $6-9$ & $6-9$ & $6-9$ & $6-9$ \\
\hline $\mathrm{EC}(\mu \mathrm{s} / \mathrm{cm})$ & $<400$ & 1000 & 3000 & $>3000$ & \\
\hline Dissolved oxygen (mg/L) & $>8$ & 6 & 3 & $<3$ & \\
\hline Ammonium nitrogen (mg/L) & $<0.2$ & 1 & 2 & $>2$ & \\
\hline Nitrate nitrogen (mg/L) & $<3$ & 10 & 20 & $>20$ & \\
\hline Orthophosphate (mg/L) & $<0.05$ & 0.16 & 0.65 & $>0.65$ & \\
\hline
\end{tabular}


Table 2. Class limit values and trophic status for diatom indices (BDI, GDI, TDI)

\begin{tabular}{|c|c|c|c|c|c|}
\hline $\begin{array}{c}\text { BDI score } \\
(1-20)\end{array}$ & $\begin{array}{c}\text { GDI score } \\
(1-20)\end{array}$ & $\begin{array}{c}\text { TDI score } \\
(0-100)\end{array}$ & Water quality class & Ecological status & Trophic status \\
\hline$>17$ & $>17$ & $<35$ & I. class & High & Oligotrophic \\
\hline $15-17$ & $14-17$ & $35-50$ & II. class & Good & Oligo-Mesotrophic \\
\hline $12-15$ & $11-14$ & $50-60$ & III. class & Moderate & Mesotrophic \\
\hline $9-12$ & $8-11$ & $60-75$ & IV. class & Low/ Poor & Eutrophic \\
\hline$<9$ & $<8$ & $>75$ & V. class & Bad & Hypertrophic \\
\hline
\end{tabular}

log-transformed to maintain their normal distributions before the analysis. If the abundance of the taxa were less than $10 \%$ of the samples, they were excluded from the analyses to minimize the influence of the rare ones [Lavoie et al. 2009].

\section{RESULTS}

\section{Physico-chemical and nutrient variables}

The values of physicochemical parameters are listed in Table 3. According to the Spearman correlation analysis, while the TSS

Table 3. The seasonal values of physical and chemical variables measured at the sampling sites on Mert Stream water

\begin{tabular}{|c|c|c|c|c|c|c|}
\hline \multicolumn{2}{|r|}{ Parameters } & Summer & Autumn & Winter & Spring & Mean \\
\hline \multirow{8}{*}{$\begin{array}{l}\bar{c} \\
\frac{\overline{0}}{+\frac{\pi}{\pi}} \\
\frac{ \pm}{\infty}\end{array}$} & Water Temperature $\left({ }^{\circ} \mathrm{C}\right)$ & 18.4 & 10.8 & 3.9 & 13.7 & 11.7 \\
\hline & Dissolved Oxygen (mg/L) & 9.4 & 11.2 & 13.1 & 10.4 & 11 \\
\hline & $\mathrm{pH}$ (pH unit) & 7.9 & 7.6 & 8 & 7.2 & 7.7 \\
\hline & Electrical Conductivity ( $\mu \mathrm{s} / \mathrm{cm})$ & 1087 & 923 & 807 & 860 & 919 \\
\hline & Total suspended solids (mg/L) & 2.8 & 3.4 & 0.7 & 0.6 & 1.9 \\
\hline & Nitrate $\left(\mathrm{NO}_{3}\right)(\mathrm{mg} / \mathrm{L})$ & 1.1 & 2.9 & 1.1 & 0.4 & 1.4 \\
\hline & Ammonium $\left(\mathrm{NH}_{4}^{+}\right)(\mathrm{mg} / \mathrm{L})$ & 0.2 & 0 & 0 & 0 & 0.1 \\
\hline & Orthophosphate $\left(\mathrm{o}-\mathrm{PO}_{4}\right)(\mathrm{mg} / \mathrm{L})$ & 1.3 & 1 & 0.9 & 0.6 & 1 \\
\hline \multirow{8}{*}{ 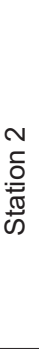 } & Water Temperature $\left({ }^{\circ} \mathrm{C}\right)$ & 24.9 & 14.2 & 4.2 & 16.5 & 15 \\
\hline & Dissolved Oxygen (mg/L) & 8 & 10.4 & 13.3 & 9.9 & 10.4 \\
\hline & $\mathrm{pH}$ (pH unit) & 7.4 & 7.8 & 7.7 & 7.1 & 7.5 \\
\hline & Electrical Conductivity ( $\mu \mathrm{s} / \mathrm{cm})$ & 873 & 743 & 603 & 720 & 735 \\
\hline & Total suspended solids (mg/L) & 2.8 & 3.4 & 0.7 & 0.6 & 1.9 \\
\hline & Nitrate $\left(\mathrm{NO}_{3}\right)(\mathrm{mg} / \mathrm{L})$ & 0.5 & 0.7 & 1 & 1 & 0.8 \\
\hline & Ammonium $\left(\mathrm{NH}_{4}^{+}\right)(\mathrm{mg} / \mathrm{L})$ & 0.01 & 0 & 0.02 & 0 & 0 \\
\hline & Orthophosphate $\left(\mathrm{o}-\mathrm{PO}_{4}\right)(\mathrm{mg} / \mathrm{L})$ & 1.3 & 0.3 & 0.8 & 0.7 & 0.8 \\
\hline \multirow{8}{*}{ 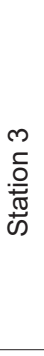 } & Water Temperature $\left({ }^{\circ} \mathrm{C}\right)$ & 21.8 & 10.8 & 4.2 & 15.5 & 13.1 \\
\hline & Dissolved Oxygen (mg/L) & 8.7 & 11.3 & 13 & 9.9 & 10.7 \\
\hline & $\mathrm{pH}$ (pH unit) & 7.3 & 7.9 & 7.9 & 7.5 & 7.7 \\
\hline & Electrical Conductivity ( $\mu \mathrm{s} / \mathrm{cm})$ & 1173 & 940 & 763 & 907 & 946 \\
\hline & Total suspended solids (mg/L) & 35.3 & 13.7 & 6.7 & 13.3 & 17.3 \\
\hline & Nitrate $\left(\mathrm{NO}_{3}\right)(\mathrm{mg} / \mathrm{L})$ & 3.3 & 0.8 & 1.3 & 1.3 & 1.7 \\
\hline & Ammonium $\left(\mathrm{NH}_{4}^{+}\right)(\mathrm{mg} / \mathrm{L})$ & 0 & 0 & 0 & 0 & 0 \\
\hline & Orthophosphate $\left(\mathrm{o}-\mathrm{PO}_{4}\right)(\mathrm{mg} / \mathrm{L})$ & 1.1 & 0.6 & 0.7 & 0.3 & 0.7 \\
\hline \multirow{8}{*}{ 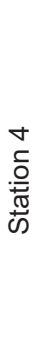 } & Water Temperature $\left({ }^{\circ} \mathrm{C}\right)$ & 25.4 & 15 & 6.1 & 15.8 & 15.6 \\
\hline & Dissolved Oxygen (mg/L) & 8.2 & 10.3 & 12.4 & 9.9 & 10.2 \\
\hline & $\mathrm{pH}$ (pH unit) & 7.1 & 7.6 & 7.4 & 7.8 & 7.5 \\
\hline & Electrical Conductivity ( $\mu \mathrm{s} / \mathrm{cm})$ & 1410 & 1020 & 723 & 920 & 1018 \\
\hline & Total suspended solids (mg/L) & 121.7 & 87.7 & 45.0 & 96.7 & 87.8 \\
\hline & Nitrate $\left(\mathrm{NO}_{3}\right)(\mathrm{mg} / \mathrm{L})$ & 1.6 & 3 & 1.6 & 0.6 & 1.7 \\
\hline & Ammonium $\left(\mathrm{NH}_{4}^{+}\right)(\mathrm{mg} / \mathrm{L})$ & 0 & 0 & 0 & 0 & 0 \\
\hline & Orthophosphate $\left(\mathrm{o}-\mathrm{PO}_{4}\right)(\mathrm{mg} / \mathrm{L})$ & 1.2 & 0.4 & 1.2 & 0.3 & 0.8 \\
\hline
\end{tabular}


parameter showed a positive correlation at the 1 st and 2nd stations monthly, this parameter showed a positive correlation only with the 4th station on a seasonal and total organism basis. The Temperature and DO parameters showed a positive and negative correlation with seasons at all four stations $(\mathrm{p}<0.05)$, while they showed a correlation only with stations 2 and 4 with total organisms (Table 4). There were significant differences for TSS and conductivity between stations $(\mathrm{p}<0.01)$. There were also significant differences for temperature and DO between months and seasons $(\mathrm{p}<0.01)$, (Table 5).

\section{Diatom community structure}

A total of 104 epilithic diatom species, belonging to 44 genera, were identified in the Mert Stream. The six most dominant taxa were Cymbella, Encyonema, Fragillaria, Gomphonema, Navicula, and Nitzschia. The most dominant diatom was Navicula in other stations. Among the diatoms, Diatoma vulgaris, Navicula veneta, Navicula cryptocephala, Eolimna minima, and Cymbella affinis were the most dominant species in the stations 1 and 2 while Cymbella ventricosa, Epithemia turgida, Gomphonema olivaceum, Gomphonema parvulum, and Psammothidium hustedtii were commonly found species in the samples collected at stations 3 and 4 .

\section{Diatom abundance}

The seasonal abundance of epilithic diatoms at the sampling stations of the Mert Stream is given in Figure 2. There was a significant seasonal variation in the epilithic diatom community with high cell density in summer and low abundance in winter. The highest diatom abundance (1987 cells $/ \mathrm{cm}^{2}$ ) was observed in the summer season while the lowest $\left(134\right.$ cells $\left./ \mathrm{cm}^{2}\right)$ was found in the winter season at the same station ( $\mathrm{St} 2)$.

The summer diatom abundance of the second station was distinctly different from other stations. Three different "zones" were determined from low to high abundance, according to the epilithic diatom abundance: St4, St3 and St1, and St2. However, there was also a seasonal difference in the epilithic diatom abundance: winter

Table 4. Spearman rank correlation coefficients between environmental variables and months, seasons and total organisms at each sampling station $(* \mathrm{p}<0.05 ; * * \mathrm{p}<0.01)$

\begin{tabular}{|l|c|c|c|c|c|c|c|c|c|c|c|c|}
\hline \multirow{2}{*}{ Parameters } & \multicolumn{4}{|c|}{ Months } & \multicolumn{4}{c|}{ Seasons } & \multicolumn{4}{c|}{ Total organisms } \\
\cline { 2 - 13 } & St.1 & St.2 & St.3 & St.4 & St.1 & St.2 & St.3 & St.4 & St.1 & St.2 & St.3 & St.4 \\
\hline Temp $\left({ }^{\circ} \mathrm{C}\right)$ & -0.028 & 0.162 & -0.084 & 0.266 & $-0.648^{*}$ & $-0.587^{*}$ & $-0.627^{*}$ & $-0.583^{*}$ & 0.252 & $0.817^{* *}$ & 0.186 & $0.643^{*}$ \\
\hline $\mathrm{DO}(\mathrm{mg} / \mathrm{L})$ & 0.025 & -0.210 & 0.133 & -0.252 & $0.695^{*}$ & $0.627^{*}$ & $0.669^{*}$ & $0.584^{*}$ & -0.253 & $-0.827^{* *}$ & -0.196 & $-0.690^{*}$ \\
\hline $\mathrm{pH}$ & 0.214 & -0.133 & 0.448 & 0.105 & 0.357 & 0.476 & 0.173 & -0.086 & -0.298 & -0.280 & $-0.594^{*}$ & -0.084 \\
\hline $\mathrm{TSS}(\mathrm{mg} / \mathrm{L})$ & $0.658^{*}$ & $0.658^{*}$ & 0.382 & 0.161 & 0.109 & 0.109 & -0.324 & $-0.691^{*}$ & 0.081 & 0.521 & 0.224 & $0.790^{* *}$ \\
\hline $\left.\mathrm{Con}^{*} \mu \mathrm{S} / \mathrm{cm}\right)$ & -0.091 & -0.049 & 0.123 & 0.476 & 0.497 & -0.194 & 0.552 & -0.173 & -0.238 & -0.315 & -0.424 & 0.056 \\
\hline $\mathrm{NO}_{3}-\mathrm{N}(\mathrm{mg} / \mathrm{L})$ & -0.146 & -0.079 & -0.042 & 0.151 & 0.230 & 0.012 & -0.271 & 0.358 & 0.370 & -0.337 & -0.249 & 0.091 \\
\hline $\mathrm{NO}_{4}-\mathrm{N}(\mathrm{mg} / \mathrm{L})$ & 0.044 & -0.285 & - & - & -0.135 & 0.232 & - & - & 0.218 & -0.118 & - & - \\
\hline $\begin{array}{l}\mathrm{o}_{\mathrm{PO}}-\mathrm{PO}-\mathrm{P} \\
(\mathrm{mg} / \mathrm{L})\end{array}$ & -0.053 & 0.011 & 0.106 & 0.287 & 0.228 & -0.065 & 0.240 & 0.328 & -0.475 & 0.425 & 0.321 & 0.347 \\
\hline
\end{tabular}

Table 5. One way ANOVA analysis between parameter groups $(* \mathrm{p}<0.05 ; * * \mathrm{p}<0.01)$

\begin{tabular}{|l|c|c|c|c|}
\hline \multirow{2}{*}{ Parameters } & \multicolumn{4}{|c|}{$F$ value } \\
\cline { 2 - 5 } & Stations & Months & Seasons & Total organisms \\
\hline Temp $\left({ }^{\circ} \mathrm{C}\right)$ & 0.597 & $40.563^{* *}$ & $33.301^{* *}$ & 0.541 \\
\hline $\mathrm{DO}(\mathrm{mg} / \mathrm{L})$ & 0.403 & $39.387^{* *}$ & $33.296^{* *}$ & 0.498 \\
\hline $\mathrm{pH}$ & 0.532 & 3.281 & 1.869 & 0.791 \\
\hline $\mathrm{TSS}(\mathrm{mg} / \mathrm{L})$ & $69.154^{* *}$ & 0.260 & 0.959 & 798.461 \\
\hline $\mathrm{Con}(\mu \mathrm{S} / \mathrm{cm})$ & $5.127^{*}$ & 2.604 & 2.638 & 1.783 \\
\hline $\mathrm{NO}_{3}-\mathrm{N}(\mathrm{mg} / \mathrm{L})$ & 0.861 & 2.354 & 0.961 & 8.182 \\
\hline $\mathrm{NO}_{4}-\mathrm{N}(\mathrm{mg} / \mathrm{L})$ & 0.881 & 1.191 & 1.073 & - \\
\hline $\mathrm{o}^{*} \mathrm{PO}_{4}-\mathrm{P}(\mathrm{mg} / \mathrm{L})$ & 0.356 & 2.167 & $4.401^{* *}$ & 80.659 \\
\hline
\end{tabular}




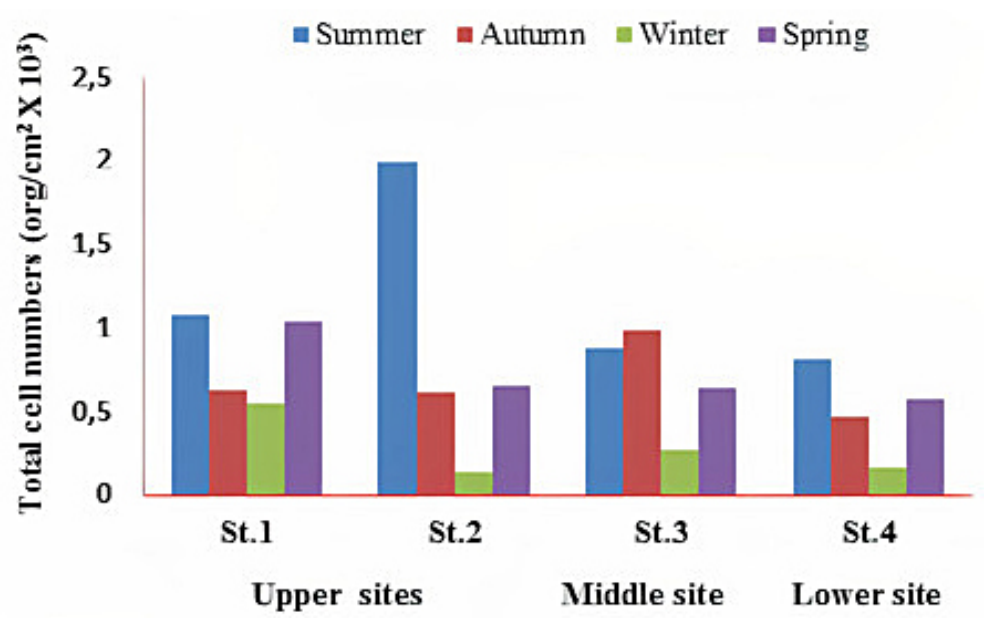

Figure 2. Seasonal abundance of the epilithic diatoms at four stations in Mert Stream

(low density), spring and autumn (moderate density), and summer (high density).

\section{Water quality and diatom metrics}

The monthly variations of the BDI (a), GDI (b), TDI (c), and WQI (d) values during the sampling period are shown in Figure 3. There were significant differences between the stations 1 and 2 and stations 3 and $4(p<0.05)$. In general, station 4 had the lowest rates of the metrics in all groups. BDI ranged from 19.3 (high quality) to 11 (poor quality) in all stations (Figure 3a). Autumn, with the average BDI value of 15.6, was the best season for water quality. BDI was significantly different among the stations $(\mathrm{p}<0.05)$. The GDI and TDI indices ranged from 16 (good quality) to 3.7 (poor quality) and from 94 (good quality) to 66 (poor quality) in four stations (Figure $3 \mathrm{~b}$ and Figure 3c). The WQI ranged from 94.4 (good quality) to 67.0 (poor quality) in four stations (Figure 3d). (a)

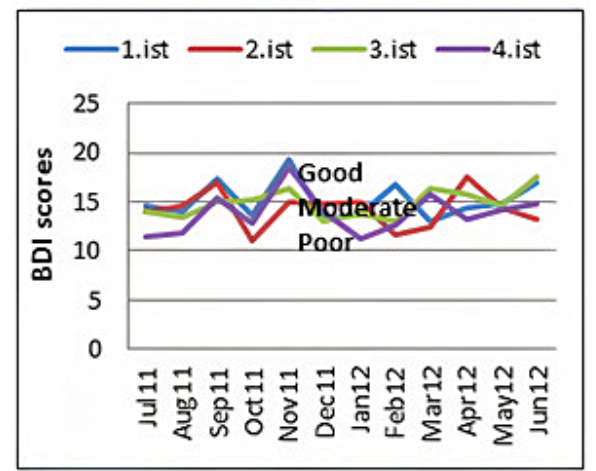

(c)

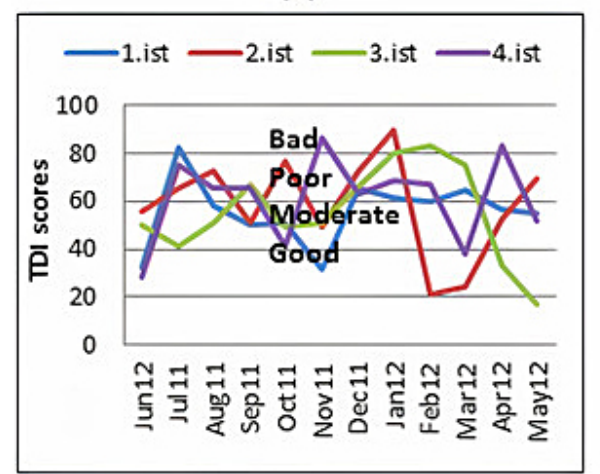

(b)

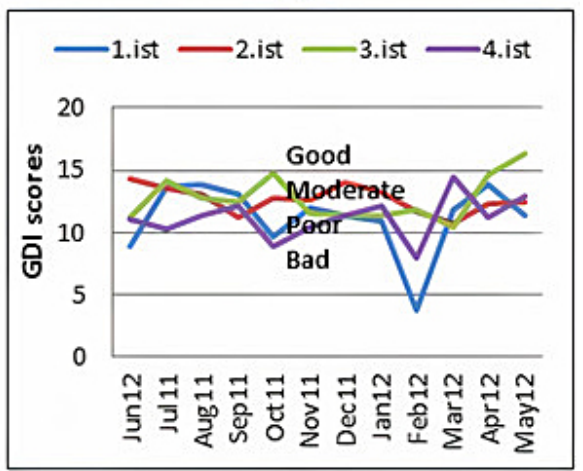

(d)

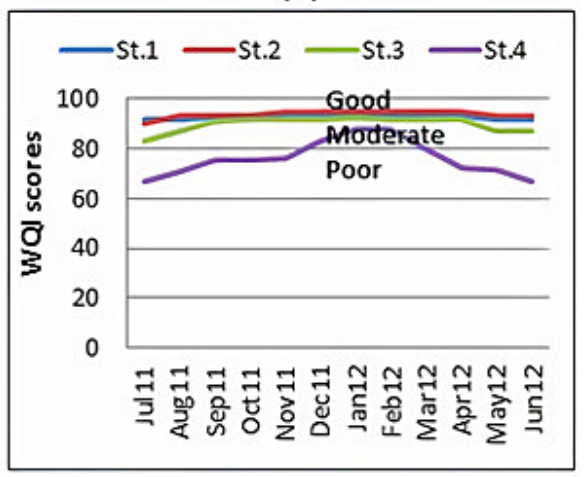

Figure 3. The monthly variation of the BDI (a), GDI (b), TDI (c), and WQI (d) values 
Table 6. Ecological status results of four sites based on physicochemical and diatom indices

\begin{tabular}{|c|c|c|c|c|c|c|}
\hline \multirow{2}{*}{} & \multicolumn{5}{|c|}{ Ecological Status } & \\
\cline { 2 - 7 } & TDI & BDI & GDI & WQI & SWQMR & Total org. \\
\cline { 2 - 7 } & poor & good & moderate & good & poor & 3279 \\
\hline St.1 & poor & moderate & moderate & good & poor & 3385 \\
\hline St.2 & moderate & moderate & moderate & moderate & poor & 2765 \\
\hline St.3 & poor & moderate & poor & poor & poor & 2003 \\
\hline St.4 & &
\end{tabular}

The ecological status of each site was determined according to the diatom and physicochemical parameters (Table 6). According to the values of Pearson's correlation between metrics and stations-seasons in Table 7, a negative correlation was determined between seasons and metric values ( $p>0.05)$. There were positive correlations between TDI and SWQMR $(p<0.01)$ as well as between TDI and GDI indices ( $<<0.05)$, (Table 7).

\section{Relation of phytoplankton assemblages to environment variables}

The relationship between the biomass of epilithic phytoplankton community and environmental factors in the stream was assessed by using the CCA analysis. Biplot of canonical correspondence analysis, relating abundance of dominant taxa and physicochemical variables in St1, St2, St3, and St4 stations were exhibited in Figure 4 (a-d). Eight environmental factors (temperature, $\mathrm{pH}, \mathrm{EC}, \mathrm{DO}, \mathrm{TSS}, \mathrm{NH}_{4}^{+}, \mathrm{NO}_{3}^{-}, \mathrm{o}-\mathrm{PO}_{4}$ ) were chosen from the environmental matrix and were used in the CCA analysis of four stations. Out of the 82 epilithic diatom species, identified in four stations, 16 abundant taxa were used in the CCA analysis (Figure 4).
In station 1 , Axis 1 was explaining $24.7 \%$ of the observed variance. DO and conductivity had high positive correlation with Axis 1(intra-set correlation coefficients: $r=0.41 ; r=0.20$, respectively). The second axis was explaining $17.1 \%$ of the observed variance and o- $\mathrm{PO}_{4}$ and temperature had a high positive correlation with Axis 2 (Figure 4a).

In station 2, the first two axes explained about $39.9 \%$ of the variance for epilithic diatom assemblages (Axis 1 accounted for 20.2\%, Axis 2 for $19.7 \%$ of the variance). The first axis is mainly defined by a combination of EC (intra-set correlation coefficients: $r=0.68$ ). Axis 2 was relatively correlated with $\mathrm{NO}_{3}^{-}$, likely to represent the water quality degradation gradient (Figure $4 b$ ).

In station 3 , the first axis was significantly correlated with abiotic factors (0.38). Axis 1 was positively correlated with the physical parameters of water, which may present a good to poor water quality gradient (Figure 4c). Axis 2 is partially correlated with DO (intra-set correlation coefficients: $r=0.58$ ). $\mathrm{NO}_{3}{ }^{-}$well correlated with axis $1(r=0.52)$, while TSS contributed significantly to axis $2(r=0.45)$ and also axis $2(r=0.42$; $r=0.23$ ), in station 4 (Figure $4 \mathrm{~d}$ ).

Table 7. Pearson correlation coefficients between metrics and stations-seasons $(* \mathrm{p}<0.05 ; * * \mathrm{p}<0.01)$

\begin{tabular}{|c|c|c|c|c|c|c|}
\hline \multicolumn{2}{|c|}{ Parameters } & \multicolumn{3}{|c|}{ Diatom indices } & \multicolumn{2}{c|}{ Water quality indices } \\
\cline { 2 - 7 } & & TDI & BDI & GDI & WQI & SWQMR \\
\hline \multirow{4}{*}{ Station } & St.1 & -0.167 & $-0.917^{*}$ & 0.000 & -0.167 & 0.500 \\
\cline { 2 - 7 } & St.2 & 0.167 & $0.917^{*}$ & 0.000 & 0.167 & -0.500 \\
\cline { 2 - 7 } & St.3 & -0.083 & 0.000 & -0.167 & $0.833^{*}$ & -0.583 \\
\cline { 2 - 7 } & St.4 & 0.417 & 0.417 & 0.333 & $1.417^{*}$ & -0.750 \\
\hline \multirow{4}{*}{ Season } & Spring & -0.167 & -0.250 & -0.167 & 0.167 & -1.000 \\
\cline { 2 - 7 } & Summer & 0.167 & 0.250 & 0.167 & -0.167 & 1.000 \\
\cline { 2 - 7 } & Autumn & 0.250 & -0.417 & 0.333 & -0.250 & 0.167 \\
\cline { 2 - 7 } & Winter & 1.083 & 0.500 & 0.333 & -0.500 & 1.000 \\
\hline \multirow{3}{*}{\begin{tabular}{l} 
Diatom indices \\
\cline { 2 - 7 }
\end{tabular}} & TDI & 1.000 & 0.214 & $0.345^{*}$ & 0.100 & $0.436^{* *}$ \\
\cline { 2 - 7 } & BDI & 0.214 & 1.000 & 0.183 & -0.029 & -0.048 \\
\hline
\end{tabular}


(a)

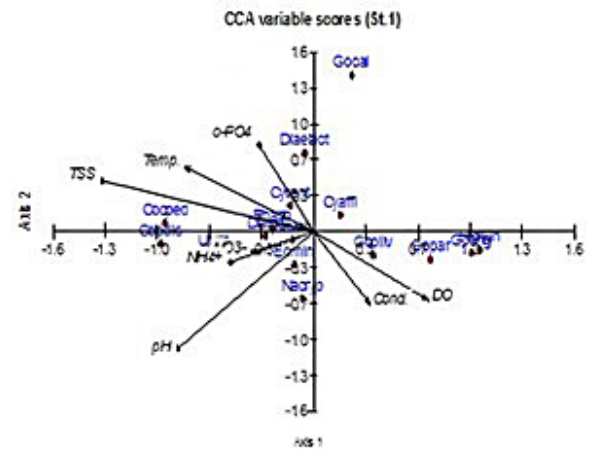

(c)

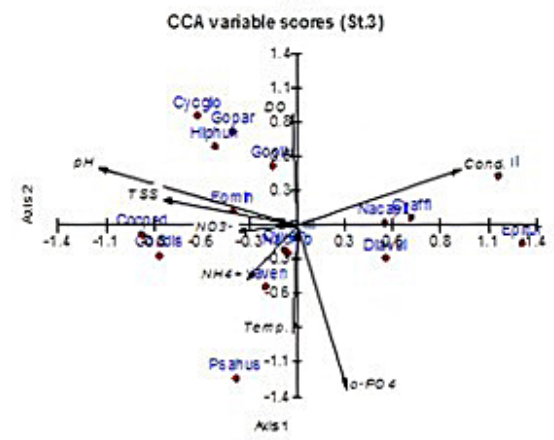

(b)

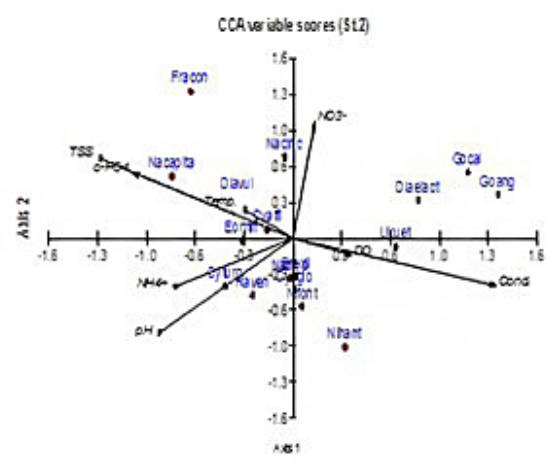

(d)

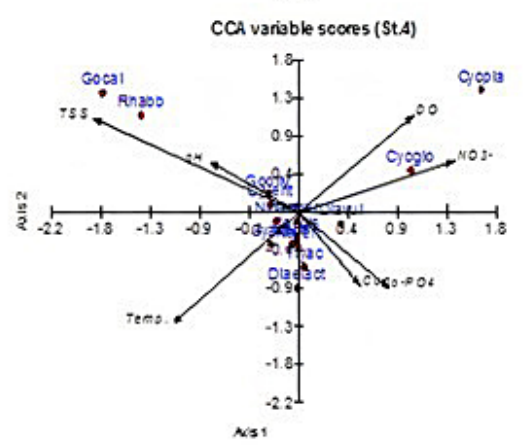

Figure 4. Biplot of canonical correspondence analysis, relating abundance of dominant taxa and physico-chemical variables in St1(a), St2 (b), St3 (c), and St4 (d) stations

The epilithic diatoms were classified as three groups in four stations, according to the CCA analysis. The first group species were present in stations 1 and 2 with higher o- $\mathrm{PO}_{4}, \mathrm{NH}_{4}^{+}$and lower $\mathrm{NO}_{3}^{-}$, TSS and EC conditions. These parameters were highly associated with the Cymbella ventricosa, Navicula capitatoradiata, N. ventricosa, Diatoma vulgaris, and Ulnaria ulna diatoms. The diatoms in stations 1 and 2, Cymbella affinis, Diatoma elongata var. actinastroides, Fragilaria construens, Gomphonema angustatum, G. calcareum, and Nitzschia hantzschiana, were not associated with any parameter. The second group species were present in station 3 with higher $\mathrm{NO}_{3}{ }^{-}$and, lower $\mathrm{NH}_{4}^{+}$and o- $\mathrm{PO}_{4}$ nutrients. Gomphonema calcareum, Navicula veneta, Cymbella ventricosa, and Eolimma minima associated with $\mathrm{EC}, \mathrm{NH}_{4}^{+}, \mathrm{TSS}, \mathrm{pH}$ respectively, while all other organisms at this station were not correlated with any parameters. Another group species were present in station 4 with high TSS, EC and temperature Those species were positively correlated with $\mathrm{NO}_{3}^{-}, \mathrm{pH}, \mathrm{TSS}$, and temperature, associating with most other diatoms such as Cyclotella glomerata, Gomphonema olivaceum, Cymbella ventricosa, Gomphonema calcareum, Rhoicosphenia abbreviata, Nitzschia hantzschiana, and Cymbella affinis.

\section{DISCUSSION}

Although intensive agricultural activity in the upper and middle sites and discharges from the industrial and residential areas in the lower site of the stream threaten the water quality of the Mert stream, no monitoring study in the stream was no conducted up to this study. Hence, this study is important since it allows determining the ecological quality of the stream.

The epilithic diatom biodiversity of the Mert Stream was positively correlated with water quality. The total number of organisms in the lower site of the stream with lower water quality was lower than the upper and middle sites with higher water quality. Similar results were reported elsewhere [Rott, Pfister 1988, Yun et al. 2014].

It was also found that there were significant correlations between the diatom indicator values and most of the environmental variables. For example, increasing temperature, EC, and TSS 
affected the diversity positively during the summer period. Temperature and oxygen were correlated with the seasons and total organisms in the Mert Stream. In turn, $\mathrm{pH}$ was correlated only with the total organisms, TSS was correlated with three different factors (months, seasons and total organisms). According to the ANOVA test, there were differences between months and seasons in terms of temperature and oxygen as expected $(\mathrm{p}<0.01)$. TSS and conductivity values also differed between stations (Table 5).

The GDI proposed in the present study characterizes the water quality according to a ratio of only five dominant genera. This makes the use of indicator simple and convenient. The ratio of abundance of genera that occurred more often in the unpolluted environments (Cocconeis and Cymbella) to those common in the polluted environments (Diatoma, Gomphonema, and Navicula) was taken as the GDI of the diatom assemblages.

The results of the diatom metrics showed that the water quality levels in the Mert Stream varied from good to poor status between stations. This has been corroborated for the biological indices which reveal that the water quality in upper and middle sites has demonstrated a good status, during the sampling period, while downstream it presented generally poor status. Increasing human pressures and municipal wastewater from upper to lower parts of the stream resulted in declining index values, as it was observed in similar studies [Lam, Vilas 2015, Le et al. 2016]. According to the BDI and GDI indices, all stations except one, poor and under eutrophication threat, are away from pollution and have good ecological conditions. The measured physicochemical parameters supported the diatom indices results, while the total number of organisms was decreasing to downstream sites. When considering three diatom indices values, the 4th station was slightly more polluted than the other stations. High EC, TSS and temperature concentrations in the 4th station support these three diatom indices. According to the BDI index, the 1st station was the cleanest station of the stream. However, the TDI and GDI indices indicated that 3 th station was the least contaminated site. When we evaluate the diatom indices seasonally, it is seen that the pollution increases in winter considering the TDI and GDI indice values (71 and 11, respectively). The three diatom indices indicated that summer and spring were seasons with the least pollution. On the basis of the BDI value (16), autumn has the highest water quality, while the cleanest season, based on TDI, was spring (71). There is a positive correlation between the TDI and GDI indices $(\mathrm{p}<0.05)$, (Table 7). However, the BDI index was not correlated with any other diatom indices ( $>>0.05$ ). According to all these results, it is considered that GDI could be better reflecting the trophic state of the Mert Stream. Standard parameters are used in the water quality index (WQI) for surface water classification [Hanh et al. 2011]. It provides a basis with which the diatom-based indices can be compared. During the study, the average values of WQI for four stations (St1, St2, St3, St4) were categorized as poor water quality for human use (93, 93, 88, 78 respectively) from 2011 to 2012. The computed average WQI (91.3) for upper and middle sites of the stream (St1, St2 and St3) indicate fairly good quality of water while the average WQI (78) for lower site of the stream (St4) indicates poor quality of water due to the domestic and industrial discharges from $\mathrm{St} 4$ into the stream. This is not surprising as St1, St2 and $\mathrm{St} 3$ are upstream, and at the edge of the part of the stream that is unaffected by direct runoff from the waste dump. In contrast, St4 is located in the urban part of the stream that receives direct runoff from the waste fill. Our results for the GDI index agreed with the WQI index. According to both metrics, the water quality in stations 1,2 and 3 were better than the station 4 . However, according to both TDI and SWQMR metrics, the water quality was low in the whole stream. However, there was a serious pollution in the river only at the 4th station. According to the results of Pearson correlation analysis conducted between the diatom and water quality metrics (Table 7), there was a strong positive correlation between TDI and SWQMR $(\mathrm{p}<0.01)$.

If the water quality was to be classified only based on some physicochemical measurements (SWQMR) as determined by the Ministry of Agriculture and Ekstrafor, all stations of the Mert Stream should be classified as 4th class (poor) water quality. However, the stream water was not so polluted according to organisms and WQI. Although some studies [Pham 2017, Stevenson et al. 2008] stated that the biological indices were more effective tools to monitor the biological quality and ecological status of the lotic systems. We suggest that some biological indices based on epilithic diatom community and WQI based on physico-chemical parameters, may be able to differentiate sites of various degrees of contamination and, therefore, 
both biotic and abiotic indices should be used in order to monitor the quality of surface waters.

Classification of the trophic state in lotic systems is most appropriately based on algal biomass and secondarily on nutrients [Dodds et al. 1998]. However, diatom was also used in evaluating the water quality since they were also sensitive to change in the water quality [Stevenson et al. 2008, Chen et al. 2016, Szulc, Szulc 2013]. The diatom species diversity, found in the Mert Stream, was similar to the one, found in other Black sea regions [Soylu et al. 2011, Maraşlığlu et al. 2016]. The diatom diversity and assemblages in the Mert Stream were divided into two groups based on their responses to environmental conditions. For example, Diatoma vulgaris, considered to be moderately tolerant to organic pollution originated from nutrients [Dokulil et al. 1997], were the dominant species in the stations 1 and 2; while Gomphonema parvulum species, thought to be tolerant of heavy pollution [Besse-Lototskaya et al. 2011], were dominant in station 4. The epilithic diatom community in the Mert stream was structured by TSS, conductivity, and nutrients. The diatom composition in station 1 and 2 was greatly influenced by high phosphate concentrations due to the surface runoff from the pesticides used in agricultural areas. In contrast, the diatom community in station 4 was highly associated with TSS and conductivity due to the emissions of urban sewage [Maraşlıoğlu et al. 2018].

A significant effect of water quality variables (EC, $\mathrm{DO}, \mathrm{NO}_{3}{ }^{-}$and o- $\mathrm{PO}_{4}$ ) on the distribution of diatom taxa was also the case according to multivariate analyses (CCA). Diatoms were separated into two groups according to the CCA analysis. The first group, including Eolimma minima, $C y$ clotella glomerata, Cymbella affinis, C. turgida, C. ventricosa, Diatoma vulgaris, Gomphonema olivaceum, G. calcareum, Navicula veneta, N. capitata, Nitzschia hantzschiana, Ulnaria ulna, and Rhoicosphenia abbreviata, seemed to be related with $\mathrm{NO}_{3}^{-}, \mathrm{o}_{-} \mathrm{PO}_{4} \mathrm{DO}$, TSS, temperature and $\mathrm{pH}$. D. vulgaris was an important species with high abundance, especially in the first and second stations during the summer period in the epilithic community. This species is reported as $\beta$-mesosaprobic [Van Dam et al. 1994]. It is also notable that the abundance of $N$. veneta was increased with the elevated concentrations of o- $\mathrm{PO}_{4}$ in July at the second station. G. olivaceum and $C$. affinis were other significant diatoms with high percentages, especially in the upstream stations.
G. olivaceum was found throughout the study period; however, the abundance of $C$. affinis species increased with elevated concentrations of nutrients in the summer period. G. olivaceum and $C$. affinis are considered as highly sensitive species avoiding the conditions worse than the $\beta$-mesosaprobic conditions [Van Dam et al. 1994, Dokulil et al. 1997]. Other species were mainly abundant during the wet period and were considered moderately tolerant to pollution, oligosaprobic to polysaprobic [Van Dam et al. 1994]. The second group, including Gomphonema calcareum, G. angustatum, G. parvulum, Diatoma elongata var. actinastroides, Cocconeis disculus, C. pediculus, Cymbella affinis, Cyclotella glomerata, C. planctonica, Epithemia turgida, Fragilaria construens, Hippodonta hungarica, Nitzschia hantzschiana, and Psammothidium hustedtii, was not associated with any environmental variables. C. disculus were not abundant in all the stations and tended to increase in the first station. C. disculus is considered as $\beta$-mesosaprobic [Van Dam et al. 1994]. The abundance of G. parvulum was significant, especially in the station 4 where pollution was higher during the dry period in epilithic diatoms. G. parvulum has been considered both $\alpha$-mesosaprobic and polysaprobic [Lobo et al. 1999]. The findings of Kobayasi, Mayama [1989] also supported our results, since they found that this taxon is highly tolerant to organic pollution. The indicator values in Van Dam et al. [1994] define $P$. hustedtii as oligosaprobic and oligotraphentic. This may explain the high number of individuals of this species found at the fourth station, where the levels of nutrients were not significant. Within this group, high abundances were also observed for $G$. calcareum in the first and in the fourth stations and C. glomerata in the second and in the fifth stations. G. calcareum showed a wide tolerance [Patrick, Reimer 1966] and is considered $\beta$-mesosaprobic; however, $C$. glomerata was considered $\alpha$ - mesosaprobic and polysaprobic [Van Dam et al. 1994]. F. contruens is described as an indicator species of $\beta$-mesosaprobic environment, being present in the waters with high concentrations of dissolved oxygen, according to Van Dam et al. [1994]. This species is tolerant of mild pollution and has an affinity for water of low BOD [Van Dam et al. 1994]. In the present study, F. contruens was found in all the samples, especially in the second station; however, its density was not so high during the studied period. However, these species were found dominant in the 
meso-eutrophic Lake Skomielno [Toporowska et al. 2008]. Other species were mainly abundant during the dry period and were considered moderately tolerant to pollution, $\beta$ - to $\alpha$ - mesosaprobic [Van Dam et al. 1994].

\section{CONCLUSIONS}

In summary, the gradients of environmental parameters and abundance of the dominant species were not increased gradually across the stations, as expected. However, EC and TSS values were significantly different in station 4 . The dominant species in stations 1 and 2,D. vulgaris and $N$. veneta, were more abundant than the other stations due to the low TSS values in these stations. The abundances of $D$. vulgaris and $N$. veneta in the second station were correlated positively with the low values of $\mathrm{EC}$ and $\mathrm{NO}_{3}{ }^{-}$parameters in the CCA. P. olivaceum, the secondary important species in the study area, showed a significant positive correlation with the elevation of DO and the lowness of conductivity in CCA. The Mert Stream was generally dominated by $\beta$-mesosaprobic and $\alpha$-mesosaprobic taxa that tolerate organic pollution induced by nutrients from agricultural activities and industrial and urban discharges.

The epilithic diatom and water quality metrics were used in this study to evaluate the usefulness of these metrics in determining the water quality of the Mert Stream. The obtained results confirmed that diatoms are much better than the physicochemical parameters in determining the water quality in a stream. Diatom metrics like GDI and water quality metrics like WQI provided important complementary information for the ecological status and conditions in the Mert Stream, Turkey. Therefore, it is better to use diatoms, along with the water physical and chemical parameters, for assessing the surface water quality. The obtained results also showed that land-use types around the stream caused marked changes in the epilithic diatom species composition and as a result of it, different water quality along Mert Stream was observed. According to the metrics that used in this study, the human-induced water pollution became a crucial problem in the lower site of the stream. Thus, necessary measures should be taken by the authorities to improve the water quality of the Mert stream for reducing the public health risks.

\section{Acknowledgements}

The authors sincerely thanks Dr. Lecturer G. Karakaş, Department of Property Protection and Security, Hitit Universtiy, for provided valuable contribution to statistical analysis in the manuscript.

\section{REFERENCES}

1. Agrawal A., Gopal K. 2013. Biomonitoring of water and waste water. Springer New Delhi Heidelberg New York Dordrecht London, pp. 166.

2. Akkoyunlu A., Akiner M.E. 2012. Pollution evaluation in streams using water quality indices: A case study from Turkey's Sapanca Lake Basin. Ecol. Indic., 18, 501-511.

3. Almeida S.F.P., Elias C., Ferreira J., Tornés E., Puccinelli C., Delmas F., Dörflinger G., Urbanič G., Marcheggiani S., Rosebery J., Mancini L., Sabater S. 2014. Water quality assessment of rivers using diatom metrics across Mediterranean Europe: A methods intercalibration exercise. Sci. Total Environ., 476-477 (1), 768-776.

4. Anonymous 2008. Water Pollution Control Regulation (WPCR). The Republic of Turkish Official Gazette No. 26786, Ankara, Turkey.

5. Anonymous 2016. Surface Water Quality Management Regulation (SWQMR). The Republic of Turkish Official Gazette No. 29797, Ankara, Turkey.

6. Bakan G., Şenel B. 2000. Research on Bottom Sediment and Water Quality of Samsun-Mert Stream at the Discharge into the Black Sea. Turk. J. Eng. Environ. Sci., 24 (3), 135-142.

7. Bektaş S. 2016. Investigations on the Algal Flora of Samsun Mert Stream. Master's Thesis, Ondokuz Mayıs University, Samsun.

8. Bere T., Mangadze T., Mwedzi T. 2014. The application and testing of diatom-based indices of stream water quality in Chinhoyi Town, Zimbabwe. Water SA, 40, 503-512.

9. Besse-Lototskaya A., Verdonschot. P.F.M., Coste M., Van de Vijver B. 2011. Evaluation of European diatom trophic indices. Ecol. Indic., 11 (2), 456-467.

10. Chaurasia A.K., Pandey H.K., Tiwari S.K., Prakash R., Pandey P., Ram A. 2018. Groundwater Quality assessment using Water Quality Index (WQI) in parts of Varanasi District, Uttar Pradesh, India. J. Geol. Soc. India, 92, 76-82.

11. Chen X., Zhou W., Pickett S.T.A., Li W., Han L., Ren Y. 2016. Diatoms are better indicators of urban stream conditions: A case study in Beijing, China. Ecol. Indic., 60, 265-274. https://doi.org/10.1016/j. ecolind.2015.06.039.

12. Coste M., Ayphassorho H. 1991. A study of water quality in Artois-Picardie bassine with the help of benthic diatomia communities: an application of diatomic index. Raport Cemagref. Bordeaux - Agence de l'Eau Artois-Picardie, Douai. 
13. Coste M., Boutry S., Tison-Rosebery J., Delmas F. 2009. Improvements of the Biological Diatom Index (BDI): Description and efficiency of the new version (BDI-2006). Ecol. Indic., 9 (4), 621-650.

14. Della Bella V., Mancini L. 2009. Freshwater diatom and macroinvertebrate diversity of coastal permanent ponds along a gradient of human impact in a Mediterranean eco-region. Hydrobiologia, 634, 25-41.

15. Descy J.P., Coste M. 1991. A test of methods for assessing water quality based on diatoms. Verh. Internat. Verein. Limnol., 24 (4), 2112-2116.

16. Dodds W.K., Jones J.R., Welch E.B. 1998. Suggested classification of stream trophic state: distributions of temperate stream types by chlorophyll, total nitrogen, and phosphorus. Water Res., 32 (5), 1455-1462.

17. Dokulil M.T., Schmidt R., Kofler S. 1997. Benthic diatom assemblages as indicators of water quality in a urban flood-water impoundment, Neue Donau, Vienna, Austria. Nova Hedwigia, 65, 273-283.

18. Gomà J., Rimet F., Cambra J., Hoffmann L., Ector L. 2005. Diatom communities and water quality assessment in mountain rivers of the upper Segre basin (La Cerdanya, Oriental Pyrenees). Hydrobiologia, 551 (1), 209-225.

19. Gómez N., Licursi M. 2001. The Pampean Diatom Index (IDP) for assessment of rivers and streams in Argentina. Aquat. Ecol., 35 (2), 173-181.

20. Guiry M.D., Guiry G.M. 2020. AlgaeBase. WorldWide Electronic Publication, National University of Ireland, Galway. http://www.algaebase.org/ (accessed 04 June 2020).

21. Gürbüz H., Kıvrak E. 2002. Use of the epilithic diatoms to evaluate water quality in the Karasu River of Turkey. J. Environ. Biol., 23, 239-246.

22. Hanh P.T.M., Sthiannopkao S., Ba D.T., Kim K.W. 2011. Development of Water Quality Indexes to identify pollutants in Vietnam's surface water. J. Environ. Eng., 137 (4), 273-283.

23. Hering D., Johnson R.K., Kramm S., Schmutz S., Szoszkiewicz K., Verdonschot P.F.M. 2006. Assessment of European streams with diatoms, macrophytes, macroinvertebrates and fish: a comparative metric-based analysis of organism response to stress. Freshwater Biol., 51 (9), 1757-1785

24. Jüttner I., Rothfritz H., Ormerod S.J. 1996. Diatoms as indicators of river quality in the Nepalese Middle Hills with consideration of the effects of habitatspecific sampling. Freshwater Biol., 36, 475-486.

25. Kalyoncu H., Çiçek N.L., Akköz C., Yorulmaz B. 2009. Comparative performance of diatom indices in aquatic pollution assessment. Afr. J. Agric. Res., 4, 1032-1040.

26. Kelly M.G., Adams C., Graves A.C., Jamieson J., Krokowski J., Lycett E., Murray-Bligh J., Pritchard S., Wilkins C. 2001. The Trophic Diatom Index: A user's manual. E2/TR2. (Almondsbury, Bristol: Environmental Agency, England), pp. 135.

27. Kelly M.G., Whitton B.A. 1995. The Trophic Diatom
Index: A New Index for Monitoring Eutrophication in Rivers. J. Appl. Phycol., 7 (4), 433-444.

28. Kobayasi H., Mayama S. 1989. Evaluation of River Water Quality by Diatoms. Korean J. Phycol., 4 (2), 121-133.

29. Kovach W. 1998. Multi-Variate Statistical Package. Version 3.01. Pentraeth.

30. Krammer K., Lange-Bertalot H. 1991-1999. Bacillariophyceae. 1-4. [In:] Ettl H., J. Gerloff, H. Heyning., D. Mollenhauer (eds), Süsswasserflora von Mitteleuropa 2(1-4). G. Fischer Verlag, Stuttgart - New York - Jena.

31. Kwandrans J., Eloranta P., Kawecka B., Wojtan K. 1998. Use of benthic diatom communities to evaluate water quality in rivers of southern Poland. J. Appl. Phycol., 10 (2), 193-200.

32. Lam N.V.T., Vilas N. 2015. Assessment of vulnerabilities to climate change for urban water and wastewater infrastructure management: Case study in Dong Nai river basin, Vietnam. Environ. Dev., $16,119-137$.

33. Lavoie I., Dillon P.J., Campeau S. 2009. The effect of excluding diatom taxa and reducing taxonomic resolution on multivariate analysis and stream bioassessment. Ecol. Indic., 9 (2), 213-225.

34. Le T.M.T., Dan N.P., Tuc D.Q., Ngo H.H., Lan-Chi D.H. 2016. Presence of e-EDCs in surface water and effluents of pollution sources in Sai Gon and Dong Nai river basin. Sustain, Environ. Res., 26 (1), 20-27.

35. Lenoir A., Coste M. 1996. Development of a practical diatom index of overall water quality applicable to the French national water board network. [In:] Whitton B.A., Rott E. (eds), Use of algae for monitoring rivers II, Institut für Botanik. Univ Innsbruck, Innsbruck. 29-43.

36. Liu S., Xie G., Wang L., Cottenie K., Liu D., Wang B. 2016. Different roles of environmental variables and spatial factors in structuring stream benthic diatom and macroinvertebrate in Yangtze River Delta, China. Ecol. Indic., 61 (2), 602-611.

37. Lobo E.A., Ben da Costa A., Kirst A. 1999. Avaliação da qualidade da água dos arroiosSampaio, Bonito e Grande, Município de Mato Leitão, RS, Brasil, segundo a resoluçãodo CONAMA 20/86. Rev. Redes., 4 (2), 129-146.

38. Lobo E.A., Katoh K., Aruga Y. 1995. Response of epilithic diatom assemblages to water pollution in rivers located in the Tokyo Metropolitan area, Japan. Freshwater Biol., 34 (1), 191-204.

39. Maraşlıŏlu F., Gönülol A., Baş-Pelit G. 2016. Relationship between Some Physicochemical Variables and Epilithic Algae of Tersakan Stream (SamsunAmasya, Turkey). Black Sea J. Sci., 6 (14), 1-11.

40. Maraşlıoğlu F., Gönülol A., Bektaş S. 2018. The use of water quality index method to determine the quality of surface water in the Mert Stream (Samsun, Turkey). J. Biol. Ser., 1, 11-17. 
41. Maraşlıoğlu F., Gönülol A. 2020. Turkish algae electronic publication. http://turkiyealgleri.hitit. edu.tr. (accessed 22 May 2020)

42. Newall P., Walsh C.J. 2005. Response of epilithic diatom assemblages to urbanization influences. Hydrobiologia, 532, 53-67.

43. Ongun-Sevindik T., Küçük F. 2016. Benthic Diatoms as Indicators of Water Quality in the Acarlar Floodplain Forest (Northern Turkey). Fresen. Environ. Bull., 25 (10), 4013-4025.

44. Pandey L.K., Lavoie I., Morin S., Park J., Lyu J., Choi S., Lee H., Han T. 2018. River water quality assessment based on a multi-descriptor approach including chemistry, diatom assemblage structure, and non-taxonomical diatom metrics. Ecol. Indic., 84, 140-151.

45. Patrick R., Reimer C.W. 1966. The diatoms of the United States. Academy of Natural Sciences, Philadelphia, pp. 688.

46. Pham T.L. 2017. Comparison between Water Quality Index (WQI) and biological indices, based on planktonic diatom for water quality assessment in the Dong Nai River, Vietnam. Pollut., 3 (2), 311-323.

47. Prygiel J., Coste M. 1993. The assessment of water quality in the Artois-Picardie water basin (France) by the use of diatom indices. Hydrobiologia, 269 (1), 343-349.

48. Ravera O. 2001. A comparison between diversity, similarity and biotic indices applied to the macroinvertebrate community of a small stream: the Ravella river (Como Province, Northern Italy). Aquat. Ecol., 35 (2), 97-107.

49. Rott E., Pipp E., Pfister P. 2003. Diatom methods developed for river quality assessment in Austria and a cross-check against numerical trophic indication methods used in Europe. Arch. Hydrobio., 110: 91-115.

50. Rott E., Pfister P. 1988. Natural epilithic algal communities in fast-flowing mountain streams and rivers and some man-induced changes. Verh. Internat. Verein. Limnol., 23 (3), 1320-1324.

51. Round F.E., Crawford R.M., Mann D.G. 1990. The Diatoms: Morphology and biology of the genera. Cambridge University Press, Cambridge, pp. 747.

52. Rumeau A. Coste M. 1988. Introduction into the Systematic of Freshwater Diatoms: For a useful generic diatomic index. B. Fr. Peche. Piscic., 309, $1-69$.

53. Sebastiá M., Rodilla M., Falco S., Sanchis J. 2013. Analysis of the effects of wet and dry seasons on a Mediterranean river basin: Consequences for coastal waters and its quality management. Ocean. Coast. Manage., 78, 45-55.

54. Semenchenko V.P., Moroz M.D. 2005. Comparative analysis of biotic indices in the monitoring system of running water in a biospheric reserve. Water
Res., 32 (2), 200-203. https://doi.org/10.1007/ s11268-005-0025-0.

55. Smol J.P., Stoermer E.F. 2010. The Diatoms: Applications for the Environmental and Earth Sciences. Cambridge University Press, Cambridge, pp. 667.

56. Solak C.N., Ector L., Wojtal A.Z., Acs E., Morales E.A. 2012. A review of investigations on diatoms (Bacillariophyta) in Turkish inland waters. Nova Hedwigia, 141, 431-462.

57. Solak C.N., Fehér G., Barlas M., Pabuçcu K. 2007. Use of epilithic diatoms to evaluate water quality of Akçay Stream (Büyük Menderes River) in Mugla/ Turkey. Large Rivers, 17 (3-4), 327-338.

58. Soylu E.N., Maraşlığlu F., Gönülol A. 2011. Epiphytic diatom flora of Liman lake (Bafra-Samsun). Ekoloji, 20, 57-62.

59. Stevenson R.J., Pan Y., Manoylov K.M., Parker C.A., Larsen D.P., Herlihy A.T. 2008. Development of diatom indicators of ecological conditions for streams of the western US. J. North Am. Benthol. Soc., 27 (4), 1000-1016.

60. Szulc B., Szulc K. 2013. The use of the Biological Diatom Index (BDI) for the assessment of water quality in the Pilica River, Poland. Oceanol. Hydrobiol. St., 42 (2), 188-194.

61. Tan X., Sheldon F., Bunn S.E., Zhang Q. 2013. Using diatom indices for water quality assessment in a subtropical river, China. Environ. Sci. Pollut. Res., 20, 4164-4175.

62. Temizel B., Soylu E.N., Maraşlığlu F. 2017. Water quality assessment of the Pazarsuyu Stream based on epilithic diatom communities. Fund. Appl. Limnol., 190 (3), 189-197.

63. Toporowska M., Pawlik-Skowrońska B., Wojtal A.Z. 2008. Epiphytic algae on Stratiotes aloides L., Potamogeton lucens L., Ceratophyllum demersum L. and Chara spp. in a macrophyte-dominated lake. Oceanol. Hydrobiol. St., 37 (2), 51-63.

64. Van Dam H., Mertens A., Sinkeldam J. 1994. A coded checklist and ecological indicator values of freshwater diatoms from the Netherlands. Neth. J. Aquat. Ecol., 28 (1), 117-133.

65. Vörösmarty C.J., McIntyre P.B., Gessner M.O., Dudgeon D., Prusevich A., Green .P, Glidden S., Bunn S.E., Sullivan C.A., Reidy Liermann C., Davies P.M., 2010. Global threats to human water security and river biodiversity. Nature, 467, 555-561.

66. Yu S.F., Lin H.J. 2009. Effects of agriculture on the abundance and community structure of epilithic algae in mountain streams of subtropical Taiwan. Botanical Studies, 50, 73-78.

67. Yun S.M., Hyoung M.J., Seung W.J., Chung H.C., Jang-Seu K., Jin H.L. 2014. The relationship between epilithic diatom communities and changes in water quality along the lower Han River, South Korea. J. Freshwater Ecol., 29 (3), 363-375. 